\title{
Fuzzy-VIKOR analysis for customer performance index of civil domestic airline industry in India
}

\author{
Suman Saket ${ }^{\mathrm{a}^{*}}$, Amritpal Singh ${ }^{\mathrm{a}}$ and Dinesh Khanduja ${ }^{\mathrm{b}}$
}

${ }^{a}$ Department of Mechanical Engineering, National Institute of Technology, Kurukshetra, Haryana, India, 136119

${ }^{b}$ Professor, Department of Mechanical Engineering, National Institute of Technology, Kurukshetra, Haryana, India, 136119

\section{H R O N I C L E}

Article history:

Received September 28, 2014

Accepted 15 January 2015

Available online

January 232015

Keywords:

$M A D M$

Fuzzy-VIKOR

Airline Industry

Customer Performance index

$M D L$

\section{Introduction}

In today's world, performance has a big role in an organization. Performance of an organization is measured in terms of several factors such as performance quality, financial performance, etc. Airline carrier firms are also progressing through the same phase of performance. Airline carriers have to perform well to provide appropriate services for customers. In India, rising economy, increase in population has created a window of opportunities for the Airline carriers. In this context, the most promising domestic airlines serving in India include Jet Airways $\left(\mathrm{C}_{1}\right)$, GoAir $\left(\mathrm{C}_{2}\right)$, IndiGo $\left(\mathrm{C}_{3}\right)$, Air India $\left(\mathrm{C}_{4}\right)$ and SpiceJet ( $\mathrm{C}_{5}$ ) (Airfleets aviation; Airindia, 2014; Goair, 2014). Passengers carried by domestic airlines during Jan-Jun 2014 were 324.11 lakhs (DGCA, 2014). While this number was merely 310.14 and 305.89 lakhs during 2013 and 2012, respectively (DGCA, 2014). The industry has been registering an average growth of around 4.43\% in 2013 (Shukla, Jan 21, 2014). Airports Authority of India (AAI) suggests a sustainable growth of $22 \%$ for the domestic sector in the next 5 years which

*Corresponding author. Tel: +91-1744-233522, Fax: +91-1744-233522

E-mail addresses: sumansaket25@gmail.com (S. Saket)

(c) 2015 Growing Science Ltd. All rights reserved. doi: $10.5267 / \mathrm{j} . \mathrm{msl} 1.2015 .1 .008$ 
was only $18 \%$ in the past 5 years. With expansion of the aviation sector, a substantial ballooning of the competition among the domestic airliners has become a question of survival. The companies like Kingfisher and Air Sahara have taken the wrath of the rising competition in the industry. As a result, Air Sahara was acquired by the Jet Airways while kingfisher was not able to attain a single year of profit since it got listed for aviation performances and hence was finally taken down (Kingfisher Airline Crisis Timeline, 2013). Recent report illustrates that Jet Airways, SpiceJet and Air India have a combined loss of USD 1.2 billon at the end of financial year 2014. The same year Air India has alone suffered a loss of 3900 crores. AAI has put SpiceJet on cash and carry basis list to all the airport authorities (TNN, Dec. 5, 2014). The data manifests that none of the airlines can survive unless it is able to retain its customers and can attract newer ones. Therefore, there is a strong need to emphasis on customer satisfaction to enhance brand value and customer loyalty. Thereby, the present study aims to 1.) Recapitulate brief information about the chief parameters responsible for performance of airlines, 2.) Rank the airlines as per the current scenario.

In this context, the crucial parameters were identified that are most critical to the success and prosperity of the domestic civil aviation industry in India. The next step is to calculate the CPI and rank the airlines. Such problems can be easily dealt using multiple attribute decision making (MADM) approach (Vats \& Vaish, 2013a). We have been continuously working to develop such methodologies and unfurl their novel application domains (Vats \& Vaish, 2014a, 2014b, 2014c; Vats et al., 2013; Vats et al., 2014). A variety of methods are reported under MADM category. These methods include simple additive weighting (SAW), analytic hierarchy process (AHP) (Saaty, 1990), graph theory and matrix approach (GTMA) (Rao, 2006), VlseKriterijumska Optimisacija I Kompromisno Resenje (VIKOR) (Azimi et al., 2014), technique for order preference by similarity to ideal solution (TOPSIS) (Deng, 2000) and many others. Among these, TOPSIS and VIKOR are the most outstanding multiple attribute decision making (MADM) approach, which are designed to cope with rational and irrational decision making (Opricovic \& Tzeng, 2004; Vats \& Vaish, 2013b). It has been applied to various problems ranging from evaluating supplier selection strategy (Azar et al., 2011; Sanayei et al., 2010; Shemshadi et al., 2011), group decision making (Peide \& Minghe, 2011; San Cristóbal, 2011), machine tool selection (Ayağ \& Özdemir, 2006; Ho, 2008; Yurdakul, 2004), material selection (Jahan et al., 2011; Shanian \& Savadogo, 2006) and performance evaluation (Sun, 2010). In the present study, we have employed fuzzy VIKOR approach incorporation with MDL method (Vats \& Vaish, 2014a). The present study is one of the first efforts to evaluate the performance parameters and rank the rival companies in Indian aviation sector.

\section{Evaluation Criteria}

Ten parameters have been identified for evaluation of the performance of domestic airlines in India. These are based on the discussion with various experts, airline operators, customer feedback who have travelled for identical destination in flights by distinct airlines and studies conducted by various researchers (report., 2014).

\subsection{Cost Competitiveness $\left(C_{1}\right)$}

Cost calculation of performances plays a vital role in the determination of ticket fares for the airline industry. Airline sector deals with the following expenses: 1. fixed cost (i.e. engineering expenses, administrative expenses, infrastructure expenses, insurance expenses, allowance) and 2. Variable cost (i.e. fuel cost, airport authority expenses, maintenance, passengers and food expenses).

\subsection{Advertisement $\left(C_{2}\right)$}

Advertisement is an effective tool to attract customers. It promotes the customers to purchase the company's performances and products or to prefer its brand. This leads to increment of the sale and thus market share of the airline companies. 


\subsection{Market Share $\left(C_{3}\right)$}

Airline companies are always looking for expansion in their market share by attracting mass customers and lowering price through advertising. It is a sign of relative competitiveness of one airline company's products or performances to other company's products or performances. Airline that grows its market share in a rapid manner, will increase its revenue faster than its competitors (Torlak et al., 2011).

\subsection{Customer Facilities $\left(C_{4}\right)$}

It is vital to have an up to date knowledge of customer needs. Once the needs are identified, the company can plan for the performances under techno-economic constraints. Some of the airlines have special preferences like boarding ramp for the infants, minors and medically unwell customers. The facilities of the airline business can be classified as the type of aircraft, frequency of flight, flight network, reservation, luggage space/weight allowed and the ticket booking centers.

\subsection{Punctuality $\left(C_{5}\right)$}

According to the directorate general civil aviation (DGCA), the various reasons for the cancellation of tickets in aviation in Indian industry included technical, operational, weather or punctual delays (report., 2014). The punctuality of the airlines was the major concern for the customers. Therefore, punctuality is a pivotal indicator towards customer performance.

\subsection{Safety $\left(C_{6}\right)$}

It is one of the vital factors on the mind of customers travelling via air. This includes the type of aircrafts and on flight security performance such as flight marshals. Aircraft manufactures have certain life cycle for comfortable functioning of an aircraft. So, maintenance and replacement of aircraft in due course can help the companies gain customers' trust.

\subsection{Crew Performance (C7)}

There have been several complains against various airlines to DGCA regarding the attitude and behavior of the crew members to the customers on board (Report, 2014). This includes the hospitality, enthusiasm of crew member, performance quality of air-hostess, pilots, flight marshals, cleanliness and solving the on board problems.

\subsection{Brand $\left(C_{8}\right)$}

The first experience of customer with the airline companies is through reservation and ticket purchase. Therefore, the ticket booking point is an important factor to create the brand of the airline company. The transactions regarding reservation and ticket purchase on the phone or online must be simple and swift.

\subsection{Web Strategy $\left(C_{9}\right)$}

The aviation industry with its feature of high technology, swiftness, performance quality, safety and security as well as with its infinite, ongoing low-cost e-commerce application may minimize their feature of being costly or even get rid of them. It provides an environment where the airlines reach their customers timely and reliable (Tsai et al., 2011).

\subsection{Performance Quality $\left(C_{10}\right)$}

The performance quality in the airline business is vital to increase the customers' loyalty for the product. Customers can easily shift to the other airlines, if they are not satisfied by the performance provided by them. To increase the customer loyalty, the quality of performance provided should be beyond the expectation. The performance starts from the waiting time for buying the ticket in the 
counter, the waiting time for the check-in and boarding, delay time before take-off and the waiting time for the collecting luggage.

\section{Method}

As discussed in previous section, the present study emphasizes on evaluating the performance of airline carriers on various customer satisfaction parameters using VIKOR. This is accomplished by first optimizing the parameters using MDL and then using VIKOR techniques to sum up the result.

\subsection{Modified Digital Logic (MDL)}

It is expected that the factors listed in the previous section have different impacts on the performance of the airlines and hence cannot be assigned equal weights. Thus, it becomes important to find out the priorities of each criterion. MDL is one of the well-known techniques to determine the weights of the priorities listed above (Dehghan-Manshadi et al., 2007). Based on the experts' opinions, a decision matrix is formed for a pair-wise comparison. Experts assign 1,2 and 3 for less, equal or more important parameters, respectively. Prior to formation of MDL table, we need to estimate the number of possible positive decisions by $N=n(n-1) / n$, where $n$ is number of parameters. Further summation of all positive decisions $(D)$ for a particular parameter on normalization leads to final weight $\left(W_{j}\right)$ as:

$$
W_{j}=\frac{D_{j}}{\sum_{j=1}^{n} D_{j}}
$$

\subsection{Fuzzy Logic}

Fuzzy deals with the problems where it is tough to distinguish between member and non-member objects of a problem. Fuzzy logic provides a natural framework for the management of uncertainty in expert systems to provide a systematic basis for representing and inferring inexplicit knowledge (Zadeh, 1983). It was used for multiple criteria decision making where the emphasis is on possibility rather than probability (Ribeiro, 1996). Fuzzy logic is based on a set theory. It comprises of a membership function within the interval [0,1], which describes the extent of relevance of an element for being the member of the set (Bevilacqua et al., 2006). Linguistic variables are used for all the comparisons, which are assigned numerical values without any enigma. A linguistic variable is a variable whose value are words or sentences in a natural or artificial language (Zadeh, 1975). For instance, quality is a linguistic variable if its values are assumed to be the fuzzy variables labeled as "good", "bad", "worst" rather than the actual numbers. The main application of the linguistic approach lies in the realm of humanistic system especially in the fields of artificial intelligence, linguistics, human decision processes, pattern recognition, psychology, economics and related areas (Bellman \& Zadeh, 1970). Different fuzzy numbers are used depending on their situation. In present study we use trapezoidal fuzzy numbers $\left(b_{1}, b_{2}, b_{3}, b_{4}\right)$ for $\left\{b_{1}, b_{2}, b_{3}, b_{4} \in \mathrm{R} ; b_{1} \leq b_{2} \leq b_{3} \leq b_{4}\right\}$ as shown in fig 1 . It

is often convenient to work with trapezoidal fuzzy numbers because of its simplicity and information processing in a fuzzy environment. The membership function $\mu_{b}(\mathrm{x})$ of trapezoidal fuzzy number is defined as

$$
\mu_{b}(\mathrm{x})= \begin{cases}\frac{x-b_{1}}{b_{2}-b_{1}}, & x \in\left[b_{1}, b_{2}\right] \\ \frac{1,}{b_{4}-x} & x \in\left[b_{2}, b_{3}\right] \\ b_{4}-b_{3} & x \in\left[b_{3}, b_{4}\right] \\ 0, & \text { otherwise }\end{cases}
$$




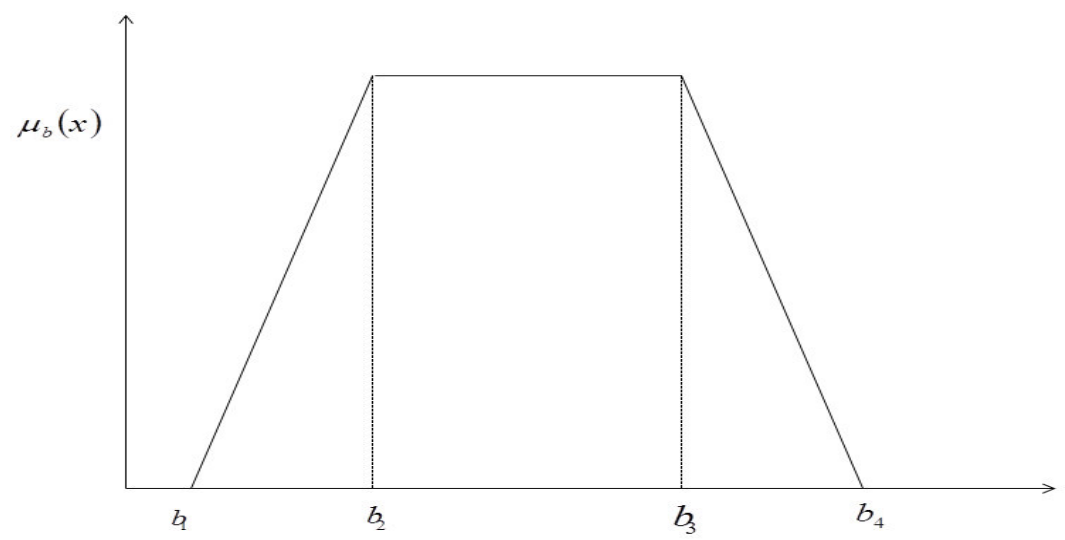

Fig. 1. Trapezoidal fuzzy number.

\subsection{VIKOR Method}

VIKOR method was developed for the optimization of MADM systems (Opricovic \& Tzeng, 2004), where the decision compiler is not able to express his/her preference at the beginning of a problem. It involves the multi criteria ranking based on particular measure of closeness to the ideal solution (Sanayei et al., 2010). The obtained compromise solution is accepted by the decision makers as it provides with a utility and regret measures. The compromise solution with the criteria weights is the basis for negotiation of decision makers' for the problem (Opricovic \& Tzeng, 2007). Normalization is used to eliminate the units of criterion functions, so that all the criteria weights are dimensionless. It is a simple transformation to obtain all criterion values in a linear way. The compromise ranking algorithm for the calculation of VIKOR index involves the following steps:

Step 6: Determination of ideal and negative ideal solutions;

The ideal solution $f^{*}$ and negative ideal solution $f^{-}$are determined as

$$
\begin{aligned}
& f^{*}=\left\{\max f_{i j}\right\} \\
& f^{-}=\left\{\min f_{i j}\right\}
\end{aligned}
$$

Step 7: Calculation of utility and regret measures

$$
\begin{aligned}
& S_{i}=\sum_{j=1}^{n} W_{j} \frac{\left(f_{j}^{*}-f_{i j}\right)}{\left(f_{j}^{*}-f_{j}^{-}\right)}, \quad \forall i \\
& R_{i}=\operatorname{Max}_{j}\left[W_{j} \frac{\left(f_{j}^{*}-f_{i j}\right)}{\left(f_{j}^{*}-f_{j}^{-}\right)}\right], \quad \forall i
\end{aligned}
$$

where $\mathrm{S}_{i}$ and $\mathrm{R}_{i}$ represent the utility and regret measures, respectively and $\mathrm{W}_{j}$ is the relative weight assigned to the $\mathrm{J}^{\text {th }}$ parameter using Fuzzy. 
Step 8: determination of VIKOR index

$$
Q_{i}=v\left[\frac{S_{i}-S^{*}}{S^{-}-S^{*}}\right]+(1-v)\left[\frac{R_{i}-R^{*}}{R^{-}-R^{*}}\right], \quad \forall i
$$

where $\mathrm{Q}_{i}$ represents $i^{\text {th }}$ alternatives VIKOR value, $v$ is the group utility weight, it is generally considered as 0.5 (unsupervised) and;

$$
\begin{aligned}
& S^{*}=\min _{i}\left(S_{i}\right), \\
& S^{-}=\max _{i}\left(S_{i}\right), \\
& R^{*}=\min _{i}\left(R_{i}\right), \\
& R^{-}=\max _{i}\left(R_{i}\right) ;
\end{aligned}
$$

The alternatives with least value of VIKOR index $\mathrm{Q}_{i}$ is preferred.

\section{Results and Discussion}

The present study emphasis on evaluating the performance of different domestic airline carrier in India on various customer satisfaction parameter. Fig 2 explicates the schematic hierarchy of the present study. Level $O$ indicates our objective that has to be determined for the shortlisted five dominant airline companies (level 1) in India namely Jet Airways, SpiceJet, Air India, GoAir, IndiGo. On the basis of our discussion with various financial experts, technical experts and customers' feedback, a group of decision compilers were formed. We have figured out that the evaluation of airline performance index primarily depends on nine criteria (level 2), explained in section 2. Interdependency of airlines on these criteria shows the complexity of the problem. Once the prime factors are identified, the next question was to prioritize these. It is important to note that these have different impacts on various airlines. Hence, in order to prioritize these, MDL approach has been used. MDL is a pair-wise comparison method in which all factors are allocated 1,2 and 3 numbers for relatively least, equal or more important parameters, respectively. The relative decision matrix formed based on MDL approach and the calculated weights are summarized in Table 1 (Eqs. (1)). Contributions of all the criteria to the airline industry are illuminated with a bar graph in Fig 3.

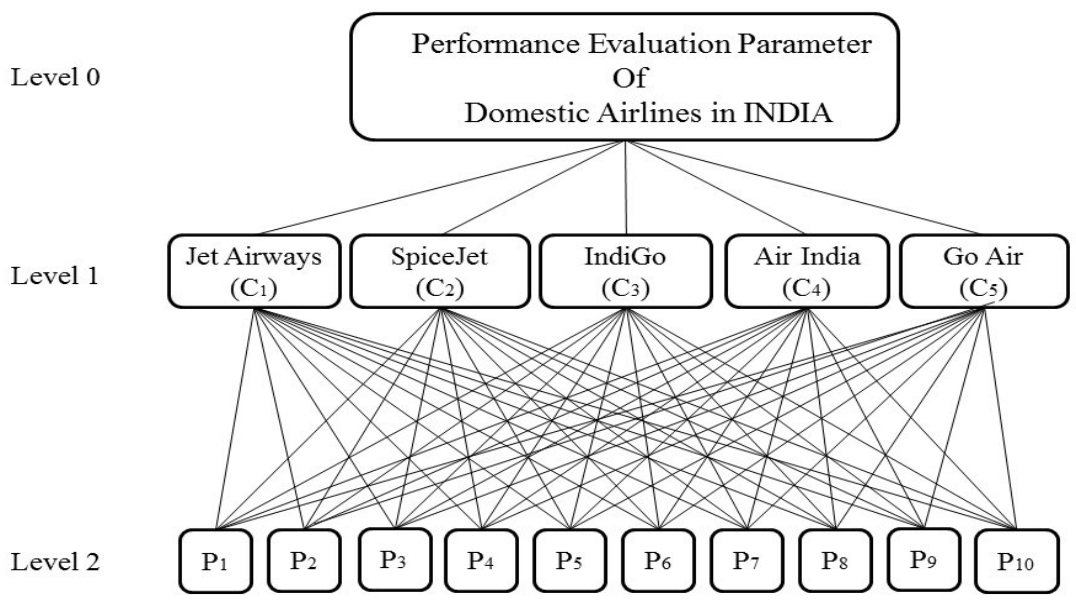

Fig. 2. Schematic hierarchy for customer Performance index in India 


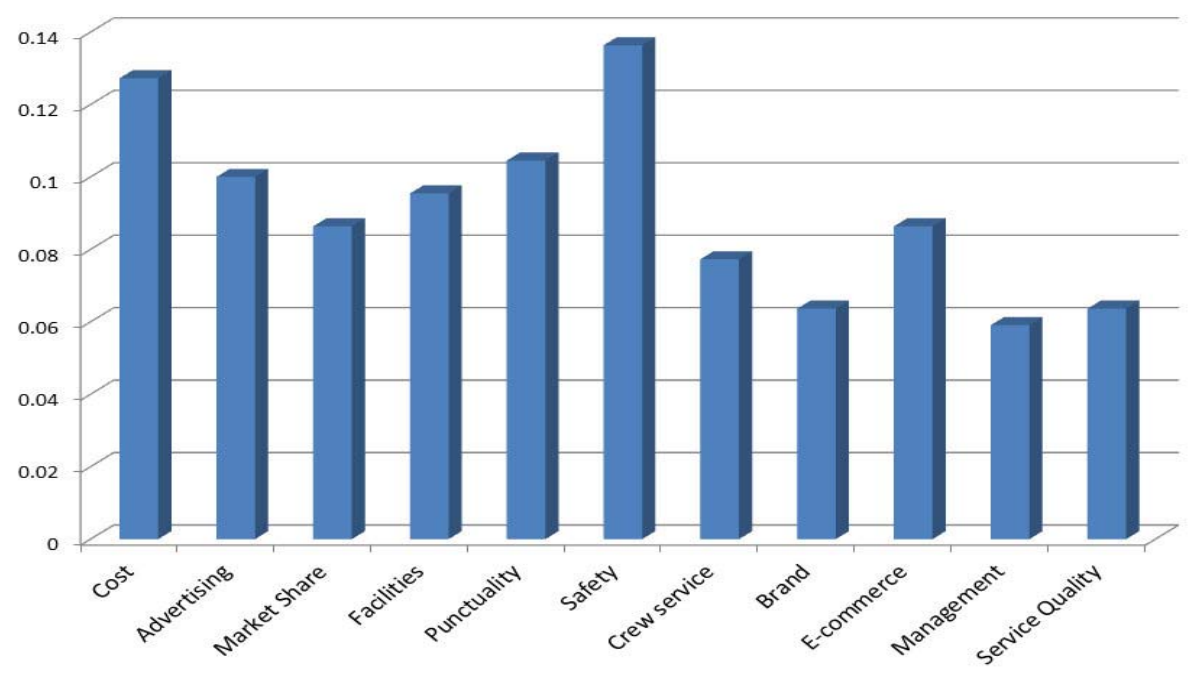

Fig. 3. Contribution of various parameters towards the customer Performance index in India (calculated using MDL)

\section{Table 1}

Subjective weights of the evaluation criteria calculated using MDL

\begin{tabular}{lccccccccccccc}
\hline Criteria & $\mathrm{P}_{1}$ & $\mathrm{P}_{2}$ & $\mathrm{P}_{3}$ & $\mathrm{P}_{4}$ & $\mathrm{P}_{5}$ & $\mathrm{P}_{6}$ & $\mathrm{P}_{7}$ & $\mathrm{P}_{8}$ & $\mathrm{P}_{9}$ & $\mathrm{P}_{10}$ & Positive Decision & Weights & Rank \\
\hline Cost $\left(\mathrm{P}_{1}\right)$ & 2 & 3 & 3 & 3 & 3 & 3 & 3 & 3 & 3 & 3 & 27 & 0.150 & 1 \\
Advertising $\left(\mathrm{P}_{2}\right)$ & 1 & 2 & 3 & 3 & 3 & 1 & 2 & 3 & 2 & 3 & 21 & 0.116 & 4 \\
Market Share $\left(\mathrm{P}_{3}\right)$ & 1 & 1 & 2 & 2 & 1 & 1 & 1 & 1 & 3 & 1 & 12 & 0.066 & 9 \\
Facilities $\left(\mathrm{P}_{4}\right)$ & 1 & 1 & 2 & 2 & 1 & 1 & 3 & 3 & 3 & 3 & 18 & 0.100 & 5 \\
Punctuality $\left(\mathrm{P}_{5}\right)$ & 1 & 1 & 3 & 3 & 2 & 1 & 3 & 3 & 3 & 3 & 21 & 0.116 & 3 \\
Safety $\left(\mathrm{P}_{6}\right)$ & 1 & 3 & 3 & 3 & 3 & 2 & 3 & 3 & 3 & 3 & 25 & 0.138 & 2 \\
Crew Service $\left(\mathrm{P}_{7}\right)$ & 1 & 2 & 3 & 1 & 1 & 1 & 2 & 3 & 1 & 3 & 16 & 0.088 & 6 \\
Brand $\left(\mathrm{P}_{8}\right)$ & 1 & 1 & 3 & 1 & 1 & 1 & 1 & 2 & 1 & 1 & 11 & 0.061 & 10 \\
Web Strategy $\left(\mathrm{P}_{9}\right)$ & 1 & 2 & 1 & 1 & 1 & 1 & 3 & 3 & 2 & 3 & 16 & 0.088 & 7 \\
Service Quality $\left(\mathrm{P}_{10}\right)$ & 1 & 1 & 3 & 1 & 1 & 1 & 1 & 3 & 1 & 2 & 13 & 0.072 & 8 \\
\hline
\end{tabular}

The next step is comparison for all airlines companies for each criterion. In this context, fuzzy approach is used as it works well where there is a need of hypothetical scale to compile the verbal reasoning of various decision makers. It utilizes linguistic variables for the comparison of different airline companies.

\section{Table 2}

Subjective weights of the evaluation criteria calculated using MDL

\begin{tabular}{ll}
\hline Linguistic Variable & Fuzzy number \\
\hline Very High (VH) & $(0.8,0.9,1.0,1.0)$ \\
High (H) & $(0.7,0.8,0.8,0.9)$ \\
Above Average (AA) & $(0.5,0.6,0.7,0.8)$ \\
Average (A) & $(0.4,0.5,0.5,0.6)$ \\
Below Average (BA) & $(0.2,0.3,0.4,0.5)$ \\
Low (L) & $(0.1,0.2,0.2,0.3)$ \\
Very Low (VL) & $(0.0,0.0,0.1,0.2)$ \\
\hline
\end{tabular}

These are further converted into fuzzy numbers using Table 2. Afterwards, the fuzzy ratings are aggregated, normalized and defuzzified. Table 3 accommodates the qualitative verbal opinion of the decision makers which is filled by us (decision compilers) based on our discussion with various decision makers. 
Table 3

Linguistic decision matrix of airlines for all evaluation criteria

\begin{tabular}{cccccc}
\hline Parameters & Jet Airways $\left(\mathrm{C}_{1}\right)$ & GoAir $\left(\mathrm{C}_{2}\right)$ & Indigo $\left(\mathrm{C}_{3}\right)$ & Air India $\left(\mathrm{C}_{4}\right)$ & \multicolumn{2}{c}{ SpiceJet $\left(\mathrm{C}_{5}\right)$} \\
\hline $\mathrm{P}_{1}$ & $\mathrm{~L}$ & $\mathrm{AA}$ & $\mathrm{H}$ & $\mathrm{A}$ & $\mathrm{BA}$ \\
$\mathrm{P}_{2}$ & $\mathrm{H}$ & $\mathrm{A}$ & $\mathrm{AA}$ & $\mathrm{BA}$ & $\mathrm{H}$ \\
$\mathrm{P}_{3}$ & $\mathrm{~A}$ & $\mathrm{H}$ & $\mathrm{VH}$ & $\mathrm{AA}$ & $\mathrm{L}$ \\
$\mathrm{P}_{4}$ & $\mathrm{H}$ & $\mathrm{AA}$ & $\mathrm{VH}$ & $\mathrm{H}$ & $\mathrm{BA}$ \\
$\mathrm{P}_{5}$ & $\mathrm{VH}$ & $\mathrm{AA}$ & $\mathrm{A}$ & $\mathrm{A}$ & $\mathrm{BA}$ \\
$\mathrm{P}_{6}$ & $\mathrm{H}$ & $\mathrm{A}$ & $\mathrm{H}$ & $\mathrm{AA}$ & $\mathrm{BA}$ \\
$\mathrm{P}_{7}$ & $\mathrm{H}$ & $\mathrm{H}$ & $\mathrm{VH}$ & $\mathrm{BA}$ & $\mathrm{L}$ \\
$\mathrm{P}_{8}$ & $\mathrm{H}$ & $\mathrm{A}$ & $\mathrm{VH}$ & $\mathrm{AA}$ & $\mathrm{VL}$ \\
$\mathrm{P}_{9}$ & $\mathrm{H}$ & $\mathrm{H}$ & $\mathrm{H}$ & $\mathrm{A}$ & $\mathrm{AA}$ \\
$\mathrm{P}_{10}$ & $\mathrm{HH}$ & $\mathrm{BA}$ & $\mathrm{A}$ & $\mathrm{AA}$ & $\mathrm{AA}$ \\
\hline
\end{tabular}

The best range is termed exceptionally high (EH) while the worst is termed extremely low (EL). Table 4 arguments the corresponding crisp values of the aggregated fuzzy ratings.

Table 4

Calculated crisp values for assigned fuzzy rates of airlines

\begin{tabular}{llllll}
\hline Evaluation Criteria & $\mathrm{C}_{1}$ & $\mathrm{C}_{2}$ & $\mathrm{C}_{3}$ & $\mathrm{C}_{4}$ & $\mathrm{C}_{5}$ \\
\hline $\mathrm{P}_{1}$ & 2.333 & 6.667 & 8.333 & 5.333 & 3.667 \\
$\mathrm{P}_{2}$ & 0.926 & 0.593 & 0.741 & 0.407 & 0.926 \\
$\mathrm{P}_{3}$ & 0.533 & 0.833 & 0.944 & 0.667 & 0.233 \\
$\mathrm{P}_{4}$ & 0.833 & 0.667 & 0.944 & 0.833 & 0.367 \\
$\mathrm{P}_{5}$ & 0.926 & 0.741 & 0.593 & 0.593 & 0.407 \\
$\mathrm{P}_{6}$ & 0.926 & 0.593 & 0.926 & 0.741 & 0.407 \\
$\mathrm{P}_{7}$ & 0.533 & 0.833 & 0.944 & 0.367 & 0.233 \\
$\mathrm{P}_{8}$ & 0.833 & 0.533 & 0.944 & 0.667 & 0.078 \\
$\mathrm{P}_{9}$ & 0.926 & 0.926 & 0.926 & 0.593 & 0.741 \\
$\mathrm{P}_{10}$ & 0.944 & 0.367 & 0.533 & 0.667 & 0.667 \\
\hline
\end{tabular}

The crisp values thus obtained are used to calculate the priority vectors for each criterion with respect to distinct airlines. Table 5 shows utility measures and rank indices for VIKOR. We sum up our study with a hope that such analysis can be proven extremely helpful for different industries while reevaluating as well as formulating their policies and strategies.

Table 5

Calculated values of utility measure for VIKOR

\begin{tabular}{|c|c|c|c|c|c|c|c|c|c|c|c|c|}
\hline \multirow[b]{2}{*}{ Airline Carrier } & \multicolumn{10}{|c|}{ Evaluation Criteria } & \multirow[b]{2}{*}{$\begin{array}{l}\text { Vikor } \\
\text { index }\end{array}$} & \multirow[b]{2}{*}{$\begin{array}{l}\text { Vikor } \\
\text { Rank }\end{array}$} \\
\hline & $P_{1}$ & $\mathrm{P}_{2}$ & $P_{3}$ & $\mathrm{P}_{4}$ & $\mathrm{P}_{5}$ & $\mathrm{P}_{6}$ & $\mathrm{P}_{7}$ & $\mathrm{P}_{8}$ & $\mathrm{P}_{9}$ & $\mathrm{P}_{10}$ & & \\
\hline Jet Airways $\left(\mathrm{C}_{1}\right)$ & 0.15 & 0.00 & 0.03 & 0.01 & 0.00 & 0.00 & 0.05 & 0.00 & 0.00 & 0.00 & 0.58 & 3 \\
\hline $\operatorname{GoAir}\left(\mathrm{C}_{2}\right)$ & 0.04 & 0.07 & 0.01 & 0.04 & 0.04 & 0.08 & 0.01 & 0.02 & 0.00 & 0.07 & 0.30 & 2 \\
\hline IndiGo $\left(C_{3}\right)$ & 0.00 & 0.04 & 0.00 & 0.00 & 0.07 & 0.00 & 0.00 & 0.00 & 0.00 & 0.05 & 0.00 & 1 \\
\hline Air India $\left(\mathrm{C}_{4}\right)$ & 0.07 & 0.11 & 0.02 & 0.01 & 0.07 & 0.05 & 0.07 & 0.02 & 0.08 & 0.03 & 0.61 & 4 \\
\hline SpiceJet $\left(\mathrm{C}_{5}\right)$ & 0.11 & 0.00 & 0.06 & 0.10 & 0.11 & 0.13 & 0.08 & 0.06 & 0.04 & 0.03 & 0.92 & 5 \\
\hline
\end{tabular}

\section{Conclusions}

Present study provides a novel application of MADM approaches in performance sector. In this context, we have identified ten factors that primarily influence the performance of domestic civil airlines in India. First, the evaluation criteria are weighted using MDL method. Cost is found to be the most optimal criterion and brand to be the least considered criterion. Thereafter, MDL weights incorporation with fuzzy has been used to obtained the crisp values. VIKOR approach was employed to calculate the performance and rank the airlines. IndiGo was found to be the best choice of Indian customers. Contemporary, GoAir and Jet Airways have been found in very close competition with each other. 


\section{References}

Airfleets aviation (2012). http://www.airindia.in/domestic-network.htm

Airindia. (2014). domestic, from http://www.airindia.in/domestic-network.htm

Ayağ, Z., \& Özdemir, R. G. (2006). A fuzzy AHP approach to evaluating machine tool alternatives. Journal of Intelligent Manufacturing, 17(2), 179-190.

Azar, A., Olfat, L., Khosravani, F., \& Jalali, R. (2011). A BSC method for supplier selection strategy using TOPSIS and VIKOR: A case study of part maker industry. Management Science Letters, 1(4), 559-568

Azimi, M., Taghizadeh, H., Farahmand, N., \& Pourmahmoud, J. (2014). Selection of industrial robots using the Polygons area method. International Journal of Industrial Engineering Computations, 5(4), 631-646.

Bellman, R. E., \& Zadeh, L. A. (1970). Decision-making in a fuzzy environment. Management science, 17(4), B-141-B-164.

Bevilacqua, M., Ciarapica, F., \& Giacchetta, G. (2006). A fuzzy-QFD approach to supplier selection. Journal of Purchasing and Supply Management, 12(1), 14-27.

Dehghan-Manshadi, B., Mahmudi, H., Abedian, A., \& Mahmudi, R. (2007). A novel method for materials selection in mechanical design: Combination of non-linear normalization and a modified digital logic method. Materials \& Design, 28(1), 8-15.

Deng, H, Y. C., Willis RJ. (2000). Inter-company comparison using TOPSIS with objective weights. Comput Oper Res 27, 963-973.

DGCA. (2014). Traffic Report.

Goair. (2014), from http://www.goair.in/menu/about-us

Ho, W. (2008). Integrated analytic hierarchy process and its applications-a literature review. European Journal of operational research, 186(1), 211-228.

Jahan, A., Mustapha, F., Ismail, M. Y., Sapuan, S., \& Bahraminasab, M. (2011). A comprehensive VIKOR method for material selection. Materials \& Design, 32(3), 1215-1221.

Kingfisher Airline Crisis Timeline. (2013). the hindu online. Retrieved from http://www.thehindu.com/business/Industry/kingfisher-airlines-crisis-timeline/article4636635.ece

Opricovic, S., \& Tzeng, G.-H. (2004). Compromise solution by MCDM methods: A comparative analysis of VIKOR and TOPSIS. European Journal of Operational Research, 156(2), 445-455. doi: http://dx.doi.org/10.1016/S0377-2217(03)00020-1

Opricovic, S., \& Tzeng, G.-H. (2007). Extended VIKOR method in comparison with outranking methods. European Journal of Operational Research, 178(2), 514-529. doi: http://dx.doi.org/10.1016/j.ejor.2006.01.020

Peide, L., \& Minghe, W. (2011). An extended VIKOR method for multiple attribute group decision making based on generalized interval-valued trapezoidal fuzzy numbers. Scientific Research and Essays, 6(4), 765-776.

Rao, R. V. (2006). A material selection model using graph theory and matrix approach. Materials Science and Engineering: A, 431(1), 248-255.

Report., D. T. (2014), from http://www.dgca.nic.in/reports/Traffic-ind.htm.

Ribeiro, R. A. (1996). Fuzzy multiple attribute decision making: a review and new preference elicitation techniques. Fuzzy sets and systems, 78(2), 155-181.

Saaty, T. L. (1990). How to make a decision: the analytic hierarchy process. European Journal of Operational Research, 48(1), 9-26.

San Cristóbal, J. (2011). Multi-criteria decision-making in the selection of a renewable energy project in spain: The Vikor method. Renewable energy, 36(2), 498-502.

Sanayei, A., Farid Mousavi, S., \& Yazdankhah, A. (2010). Group decision making process for supplier selection with VIKOR under fuzzy environment. Expert Systems with Applications, 37(1), 24-30.

Shanian, A., \& Savadogo, O. (2006). TOPSIS multiple-criteria decision support analysis for material selection of metallic bipolar plates for polymer electrolyte fuel cell. Journal of Power Sources, 159(2), 1095-1104. 
Shemshadi, A., Shirazi, H., Toreihi, M., \& Tarokh, M. J. (2011). A fuzzy VIKOR method for supplier selection based on entropy measure for objective weighting. Expert Systems with Applications, 38(10), 12160-12167.

Shukla, T. (Jan 21, 2014). http://www.livemint.com/Companies/pZ7o1VM5E8hWRKhZFer0aI/Airtraffic-registers-443-growth-in-2013.html, livemint.

Sun, C.-C. (2010). A performance evaluation model by integrating fuzzy AHP and fuzzy TOPSIS methods. Expert Systems with Applications, 37(12), 7745-7754.

TNN. (dec 5,2014). http://timesofindia.indiatimes.com/business/india-business/AAI-puts-financiallyembattled-low-cost-carrier-SpiceJet-on-cash-and-carry/articleshow/45379124.cms, times of india.

Torlak, G., Sevkli, M., Sanal, M., \& Zaim, S. (2011). Analyzing business competition by using fuzzy TOPSIS method: An example of Turkish domestic airline industry. Expert Systems with Applications, 38(4), 3396-3406.

Tsai, W.-H., Chou, W.-C., \& Leu, J.-D. (2011). An effectiveness evaluation model for the web-based marketing of the airline industry. Expert Systems with Applications, 38(12), 15499-15516.

Vats, G., \& Vaish, R. (2013a). Piezoelectric material selection for transducers under fuzzy environment. Journal of Advanced Ceramics, 2(2), 141-148. doi: 10.1007/s40145-013-0053-1

Vats, G., \& Vaish, R. (2013b). Selection of Lead-Free Piezoelectric Ceramics. International Journal of Applied Ceramic Technology.

Vats, G., \& Vaish, R. (2014a). Phase Change Materials Selection for Latent Heat Thermal Energy Storage Systems (LHTESS): An Industrial Engineering Initiative Towards Materials Science. Advanced Science Focus, 2(2), 140-147. doi: 10.1166/asfo.2014.1091

Vats, G., \& Vaish, R. (2014b). Selection of Lead-Free Piezoelectric Ceramics. International Journal of Applied Ceramic Technology, 11(5), 883-893. doi: 10.1111/ijac.12063

Vats, G., \& Vaish, R. (2014c). Selection of optimal sintering temperature of K0.5Na0.5NbO3 ceramics for electromechanical applications. Journal of Asian Ceramic Societies, 2(1), 5-10.

Vats, G., Vaish, R., \& Bowen, C. R. (2013). Selection of Ferroelectric Ceramics for Transducers and Electrical Energy Storage Devices. International Journal of Applied Ceramic Technology, n/a-n/a.

Vats, S., Vats, G., Vaish, R., \& Kumar, V. (2014). Selection of optimal electronic toll collection system for India: A subjective-fuzzy decision making approach. Applied Soft Computing, 21(0), 444-452.

Yurdakul, M. (2004). AHP as a strategic decision-making tool to justify machine tool selection. Journal of Materials Processing Technology, 146(3), 365-376.

Zadeh, L. A. (1975). The concept of a linguistic variable and its application to approximate reasoningI. Information sciences, 8(3), 199-249.

Zadeh, L. A. (1983). The role of fuzzy logic in the management of uncertainty in expert systems. Fuzzy Sets and Systems, 11(1-3), 197-198. 